\title{
MAPS SHOWING GROUND-WATER LEVELS, SPRINGS, AND \\ DEPTH TO WATER, \\ BASIN AND RANGE PROVINCE, ARIZONA
}

\begin{abstract}
by
William H. Langer, Deborah A. Mulvihill and T.W. Anderson
\end{abstract}

\section{INTRODUCTION}

This report on ground-water levels, springs and depth to ground water in the Basin and Range province of Arizona (see index map) was prepared as part of a program of the U.S. Geological survey to identify prospective regions for further study relative to isolation of high-level nuclear waste (Bedinger, Sargent, and Reed, 1984), utilizing program guidelines defined in Sargent and Bedinger (1984). Also included in this report are selected references on pertinent geologic and hydrologic studies of the region. Other map reports in this series contain detailed data on ground-water quality, surface distribution of selected rock types, tectonic conditions, areal geophysics, Pleistocene lakes and marshes, and mineral and energy resources.

\section{ACKNOWLEDGMENTS}

The authors gratefully acknowledge the review of this report by Terry Turner of the Arizona Department of Water Resources, Wesley E. Steiner, Director. 
In the Basin and Range province, ground water occurs in basin-fill deposits and consolidated rocks. The basin fill consists mostly of unconsolidated to semi-indurated sedimentary deposits. The material ranges from poorly sorted to moderately sorted mixtures of gravel, sand, silt, and clay that were derived from the consolidated rocks in the nearby mountains. Evaporite deposits, limestone, conglomerate, and volcanic rocks are present in places in the unit. Some of the basins may contain as much as 9,000 feet of basin fill, but the most permeable rocks and most of the recoverable ground water is in the upper 1,000 feet of the unit.

The consolidated rocks consist mostly of sedimentary and volcanic rocks, with lesser amounts of metamorphic and intrusive rocks. The consolidated rocks make up the mountain ranges that border the basins and are the principal source of sedimentary material to the basin fill.

Few wells exist in the consolidated rocks compared to the greater number of wells in the basin fill. The yield of wells tapping many consolidated rock units is due to interception of water in fracture zones. In some areas in the Basin and Range, carbonate rock is extensive in the subsurface and provides interconnection between alluvial basins through fractures and solution channels. Although the consolidated rock commonly has very low permeability, and very low rates of ground-water flow, the entire ground-water system, including basin fill and bedrock, must be treated as one integral system. 
The accompanying map shows the altitude of the ground-water level and the discharge and temperature of selected springs. This information was obtained primarily from reports listed in the "Selected references" and from files of the U.S. Geological Survey. The altitude of the ground-water level is shown by contours in those areas where sufficient data exist. In other areas, where regional data are inadequate to contour, data on selected wells are shown.

Ground-water-level changes occur daily, seasonally, and yearly in response to natural and man-induced hydrologic conditions. The ground-water-level map is a compilation of water-level measurements taken over a number of years. However, for any one ground-water study area the measurements generally were made during a relatively short time period. Collectively, the ground-water levels show the regional configuration of the ground-water surface.

Similarly, water temperatures and discharges of springs may vary with time. The reported values for individual springs were taken at one time; however, collectively the springs were measured over a number of years. Springs may issue from perched water tables or may be under artesian pressure; under these conditions the altitude of springs do not correspond to the altitude of the regional water table.

\section{DEPTH TO GROUND WATER}

The accompanying map shows the approximate depth to ground water below the land surface. In the basin fill, ground water moves in a continuous system, although perched ground water may occur in places. In areas with good topographic control, the depth to ground water can be predicted with reasonable accuracy between widely-spaced water-level data points, except where geologic discontinuities, such as faults, may alter the flow pattern. Where data are sufficiently closely spaced, lines of equal depth to water are shown; where data are inadequate to draw lines, data from selected wells are shown. In consolidated rocks, indicated by shaded patterns on the map, ground water occurs in poorly interconnected joints and fractures; water levels in wells may vary in depth within short distances, and numerous zones of perched water may exist.

Line patterns approximately delineate zones within which the depth to ground water is inferred to be greater than 500 feet. These are highly generalized areas based on very limited data on depth to ground water in wells tapping consolidated rock and basin fill and mine shafts; and on information gained from the location and discharge rates of springs, locations of gaining and losing reaches of streams; and estimates of geohydrologic conditions in areas. The areas delineated as possibly having depths to ground water of greater than 500 feet are recognized as having potential for evaluating prospective environments for isolation of high-level nuclear waste in the unsaturated $z$ one. 
Babcock, H. M., 1975, Annual report on ground water in Arizona with emphasis on Gila Bend Basin, McMullen Valley, and the southeast part of the Harquahala Plains-spring 1973 and Spring 1974: Phoenix, Arizona Water Commission Bulletin 9, $44 \mathrm{p}$.

Bedinger, M. S., Sargent, K. A., and Reed, J. E., 1984, Geologic and hydrologic characterization and evaluation of the Basin and Range province relative to the disposal of high-level radioactice waste--Part I, Introduction and guidelines: U.S. Geological survey Circular 904-A, [in press].

Bentley, C. B., 1979, Geohydrologic reconnaissance of Lake Mead National Recreation area-Hoover Dam to Mount Davis, Arizona: U.S. Geological Survey Open-File Report 79-690, 37 p. 1979, Geohydrologic reconnaissance of Lake Mead National Recreation area-Mount Davis to Davis Dam, Arizona: U.S. Geological Survey Open-File Report 79-691, $34 \mathrm{p}$.

City of Tucson, 1979, Maps showing depth to water and water-level contours in Avra Valley, Pima County, Arizona: City of Tucson, Unpublished Report, unpaged.

1980, Maps showing water, table elevation and depth to water in the Tucson Basin, Pima County, Arizona: City of Tucson, Unpublished Report, unpaged.

Davidson, E. S., 1973, Water-resources appraisal of the Big Sandy area, Mohave County, Arizona: Arizona water Commission Bulletin no. $6,40 \mathrm{p}$.

Denis, E. E., 1975, Maps showing groundwater conditions in the Waterman Wash area, Maricopa and Pinal Counties, Arizona-1975: Arizona Water Commission, Hydrologic Map Series, Map H-l, scale $1: 125,000,3$ sheets.

1984, Maps showing ground-water conditions in the Tonto Basin area, Gila County, Arizona: Unpublished data on file in Phoenix office of U.S. Geological Survey Water Resources Division.

Feth, J. H., and Hem, J. D., 1963, Reconnaissance of headwater springs in the Gila River drainage basin, Arizona: U.S. Geological Survey Water-Supply Paper 1619-H, $54 \mathrm{p}$.

Gillespie, J. B., Bentley, C. B., and Kam, William, 1966, Basic hydrologic data of the Hualapai, Sacramento, and Big sandy Valleys, Mohave County, Arizona: Arizona State Land Department Water Resources, no. $26,39 \mathrm{p}$.

Gould, J. A., and Wilson, R. P., 1976, Map showing ground-water conditions in the Aravaipa Valley area, Graham and Pinal Counties, Arizona - 1975: U.S. Geological Survey Water-Resources Investigations Open-File Report 76-107, scale $1: 250,000$.

Harper, R. W., and Anderson, T. W., 1976, Maps showing groundwater conditions in the Concho, st. Johns, and White Mountain areas, Apache and Navajo Counties, Arizona - 1975: U.S. Geological Survey Water-Resources Investigations OpenFile Report 76-104, 4 sheets, scale 1:250,000,52 p. 
Hollett, K. J., 1984, Maps showing ground-water conditions in the San Simon Wash area, Pima and Maricopa Counties, Arizona: Unpublished data on file in Phoenix office of U.S. Geological Survey Water Resources Division.

Jones, S. C., 1980, Maps showing ground-water conditions in the lower San Pedro Basin area, Pinal, Cochise, Pima and Graham Counties, Arizona - 1979: U.S. Geological Survey Open-File Report 80-954, scale $1: 250,000,2$ sheets.

Konieczki, A. D., 1980, Maps showing ground-water conditons in the upper San Pedro Basin area, Pima, Santa Cruz, and Cochise Counties, Arizona, 1978: U.S. Geological Survey Open-File Report 80-1192, 2 sheets.

Konieczki, A. D., and English, C. S., 1979, Maps showing ground-water conditions in the lower Santa Cruz area, Pinal, Pima, and Maricopa Counties, Arizona - 1977: U.S. Geological Survey Water Resources Investigations Open File Report 7956 , scale $1: 250,000,4$ sheets.

Laney, R. L., 1979, Geohydrologic reconnaisance of Lake Mead National Recreation area-Hoover Dam to Temple Bar, Arizona: U.S. Geological Survey Open-File Report 79-689, 42 p. 1979, Geohydrologic reconnaissance of Lake Mead National Recreation area-Temple Bar to Grand Wash Cliffs, Arizona: U.S. Geological Survey Open-File Report 79-688, 72 p.

Laney, R. L., Ross, C. P., and Littin, G. R., 1978, Maps showing ground-water conditions in the eastern part of the salt River Valley area, Maricopa and Pinal Counties, Arizona1976: U.S. Geological Survey Water-Resources Investigations Open-File Report 78-61, scale $1: 250,000,2$ sheets.

Leake, S. A., and Clay, D. M., 1979, Maps showing ground-water conditions in the Gila River drainage from Texas Hill to Dome area and in the western Mexican drainage area, Maricopa, Pima, and Yuma Counties, Arizona-1977: U.S. Geological Survey Water-Resources Investigations Open-File Report 79-1540, 2 sheets.

Levings, G. W., and Mann, L. J., 1980, Maps showing ground-water conditions in the upper verde River area, Yavapai and Coconino Counties, Arizona - 1978: U.S. Geological Survey Water Resources Open-File Report 80-726, scale $1: 250,000,2$ sheets.

Littin, G. R., 1979, Maps showing ground-water conditions in the New River-Cave Creek area, Maricopa and Yavapai Counties, Arizona - 1977: U.S. Geological Survey Water-Resources Investigations Open-File Report 79-1068, scale 1:250,000, 2 sheets.

1984, Maps showing gound-water conditions in the Agua Fria River area, Yavapai and Maricopa Counties, Arizona-1978-79: Unpublished data on file in Phoenix office of U.S. Geological Survey Water-Resources Division.

Mann, L. J., 1980, Maps showing hydrologic conditions in the san Francisco River area, Greenlee County, Arizona - 1978--A reconnaissance study: U.S. Geological survey Open-File Report 80-441, scale $1: 250,000,2$ sheets. 
Mann, L. J., and English, C. S., 1980, Maps showing groundwater conditions in the Douglas Basin area, Cochise County, Arizona, 1978: U.S. Geological Survey Water-Resources Investigations Open-File Report 80-700, scale 1:250,000, 3 sheets.

Mann, L. J., White, N. D., and Wilson, R. P., 1978, Maps showing ground-water conditions in the wilcox area, Cochise and Graham Counties, Arizona, 1975: U.S. Geological Survey Water-Resources Investigations 78-60, maps.

Matlock, W. G., Davis, P. R., and Roth, R. L., 1973, Ground-water in Little Chino Valley, Arizona: Tucson, University of Arizona, College of Agriculture, Technical Bulletin 201, 19 p.

Matlock, W. G., and Morin, G. C. A., 1975, Groundwater in the Avra and Altar Valleys, Arizona, 1974: Tucson, University of Arizona, College of Agriculture, Technical Bulletin 232, 59 p.

Ross, P. P., 1978, Maps showing ground-water conditions in the western part of the Salt River Valley area, Maricopa County, Arizona, 1977: U.S. Geological Survey Water-Resources Investigations Open-File Report 78-40, 2 sheets.

Sanger, H. W. , 1981, Maps showing ground-water conditions in the Bill Williams area, Mohave, Yuma and Yavapai Counties, Arizona: U.S. Geological Survey Water-Resources Investigations Open-File Report 82-87, scale 1,250,000, 2 sheets.

Sanger, H. W., and Appel, C. L., 1980, Maps showing ground-water conditions in the Hassayampa area, Maricopa and Yavapai Counties, Arizona, 1978: U.S. Geological Survey WaterResources Investigations open-File Report 80-584, scale $1: 250,000,2$ sheets.

Sargent, K. A., and Bedinger, M. S., 1984, Geologic and hydrologic characterization and evaluation of the Basin and Range province relative to the disposal of high-level radioactive waste--Part II, Geologic and hydrologic characterization: U.S. Geological Survey Circular 904-B, [in press].

Stulik, R. S., and Laney, R. L., 1976, Maps showing ground-water conditions in the lower Hassayampa area, Maricopa County, Arizona - 1975: U.S. Geological Survey Water-Resources Investigations Open-File Report 76-35, 3 sheets.

Wallace, B. L., and Laney, R. L., 1976, Maps showing ground-water conditions in the lower Big Chino valley and Williamson Valley areas, Yavapai and Coconino Counties, Arizona 1975 - 1976: U.S. Geological Survey Water-Resources Investigations Open-File Report 76-78, 3 sheets.

White, N. D., Leake, S. A., and Clay, D. M., 1979, Maps showing ground-water conditions in the northern part of the Gila River drainage from Painted Rock Dam to Texas Hill area, Maricopa, Pima, and Yuma Counties, Arizona 1978: U.S. Geological Survey Water Resources Investigations Open-File Report 79-1537, 3 sheets.

White, N. D., and Stulik, R. S., 1962, Annual report on ground water in Arizona, Spring 1961 to Spring 1962: Arizona State Land Department Water-Resources Report no. 11,116 p. 
Wilkins, D. W., 1978, Maps showing ground-water conditions in the Yuma area, Yuma County, Arizona, 1975: U.S. Geological Survey Water-Resources Investigations 78-62, 3 sheets.

Wilkins, D. W., and Webb, W. C., 1976, Maps showing ground-water conditions in the Ranegras Plain and Butler Valley areas, Yuma County, Arizona, 1975: U.S. Geological Survey WaterResources Investigations Open-File Report 76-34, scale $1: 250,000,2$ sheets.

Wilson, R. P., 1976, Maps showing ground-water conditions in the San Bernardino Valley area: U.S. Geological survey Water-Resources Investigations open-File Report 76-81, 2 sheets.

Wilson, R. P., and white, N. D., 1976, Maps showing ground-water conditions in the San Simon area, Cochise and Graham Counties Arizona, and in Hidalgo County, New Mexico-1975: U.S. Geological Survey Water-Resources Investigations Open-File Report 76-89, 2 sheets. 